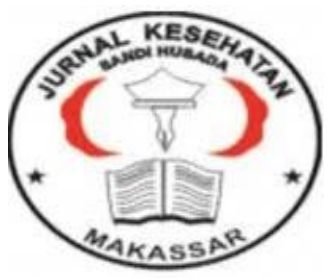

Jurnal Ilmiah Kesehatan Sandi Husada

hhttps://akper-sandikarsa.e-journal.id/IIKSH

Volume 9, Nomor 2, Desember 2020, pp 726-734

p-ISSN: 2354-6093 dan e-ISSN: 2654-4563

DOI: $10.35816 /$ jiskh.v10i2.397

\title{
Karakteristik Gejala Klinis Kehamilan dengan Coronavirus Disease (COVID-19)
}

Clinical Characteristic of Pregnancy with Coronavirus Disease (COVID-19)

Luluk Windra Yuliana

Fakultas Kedokteran Universitas Lampung

\section{Artikel info}

Artikel history:

Received; Juli 2020

Revised: Agustus 2020

Accepted; Agustus 2020

\begin{abstract}
Abstrak
Coronavirus disease 2019 (COVID-19) merupakan penyakit infeksi respiratorik akut yang menyebar dengan cepat secara global dalam waktu yang singkat. COVID-19 disebabkan oleh novel coronavirus yang diketahui sebagai Severe Acute Respiratory Syndrome Coronavirus-2 (SARS-CoV-2). Virus ini berupa RNA virus dengan rantai tunggal. Transmisi virus ini menyebar sangat cepat melalui kontak antara manusia-kemanusia (human-to-human contact) via droplet respiratorik dan saliva dari orang yang terinfeksi COVID-19. Gejala klinis COVID-19 dapat berupa simptomatik dan asimptomatik. World Health Organization (WHO) membagi gejala klinis COVID-19 yang simptomatik menjadi gejala klinis ringan, sedang, berat, dan kondisi kritis. Tulisan ini bertujuan untuk mengetahui gambaran klinis umum ibu hamil dengan infeksi COVID-19. Metode penelitian ini adalah dengan meninjau artikel review yang diterbitkan 1 tahun terakhir dengan kata kunci kehamilan, COVID-19, gejala klinis, dan coronavirus. Data menunjukkan bahwa mayoritas ibu hamil dengan COVID-19 memiliki gejala klinis yang ringan, dimana gejala utama yang muncul adalah demam, batuk, dan dispnea. Usia kehamilan tidak menentukan beratnya gejala klinis ibu hamil dan rata-rata ibu hamil dengan COVID-19 memiliki durasi rawat inap di rumah sakit yang singkat.
\end{abstract}

\section{Abstract.}

Coronavirus disease 2019 (COVID-19) is an acute respiratory infection that spreads rapidly in global by short time. COVID19 is caused by a novel coronavirus known as Severe Acute Respiratory Syndrome Coronavirus-2 (SARS-CoV-2). This virus is a single-chain RNA. Transmission of virus spreads very rapidly through human-to-human contact via respiratory droplets and saliva from people infected with COVID-19. The clinical symptoms of COVID-19 can be symptomatic and asymptomatic. The World Health Organization (WHO) divides the symptomatic clinical symptoms of COVID-19 into mild, 
moderate, severe and critical conditions. This paper aims to determine the clinical picture of pregnant women with COVID-19 infection. This research method is to review review articles published in the last 1 year with the keywords pregnancy, COVID-19, clinical symptoms, and coronavirus. Data shows that the majority of pregnant women with COVID19 have mild clinical symptoms, where the main symptoms that appear are fever, cough and dyspnea. Gestational age does not determine the severity of the clinical symptoms of pregnant women and on average pregnant women with COVID-19 have a short duration of hospitalization.

Keywords:
Pregnancy;
COVID-19;
Clinical Symptoms;

Keywords:

COVID-19;

Clinical Symptoms;
Coresponden author:

Email: windralulukyuliana@gmail.com

artikel dengan akses terbuka dibawah lisensi CC BY 4.0

\section{Pendahuluan}

Coronavirus disease 2019 (COVID-19) merupakan penyakit infeksi respiratorik akut yang menyebar dengan cepat secara global dalam waktu yang singkat. COVID-19 telah menarik perhatian dunia setelah pertama kali diidentifikasi di Cina pada 31 Desember 2019. Cina melaporkan kepada World Health Organization (WHO) bahwa pada hari tersebut ditemukan 44 pasien pneumonia berat di Kota Wuhan, Provinsi Hubei yang diduga terkait dengan pasar basah yang berada di kota tersebut. Sejak saat itu kasus penderita COVID-19 terus meningkat tajam setiap harinya. Sekitar lebih dari 51.800 kasus terkonfirmasi positif dari pemeriksaan laboratorium, dan 1.600 kematian pada 16 Februari 2020. WHO mendeklarasikan COVID-19 sebagai Kedaruratan Kesehatan Masyarakat Yang Meresahkan Dunia/ Public Health Emergency of International Concern (KKMMD/PHEIC) pada 30 Januari 2020 dan pandemik pada 11 Maret 2020 (Kementrian Kesehatan RI, 2020; Handayani, 2019; Sairah et al, 2019)

Perkembangan kasus COVID-19 tersebut hingga tanggal 25 Maret 2020, mencapai total kasus konfirmasi 414.179 dengan 18.440 kematian (CFR 4,4\%) dimana kasus dilaporkan di 192 negara/wilayah. Indonesia melaporkan kasus pertama pada tanggal 2 Maret 2020. Kasus di Indonesia pun terus bertambah, hingga tanggal 29 Maret 2020 telah terdapat 1.115 kasus dengan kematian mencapai 102 jiwa. Tingkat kematian Indonesia 9\%, termasuk angka kematian tertinggi. Pada tanggal 2 Maret 2020, Indonesia melaporkan kasus konfirmasi COVID-19 sebanyak 2 kasus. Sampai dengan tanggal 25 Maret 2020, Indonesia sudah melaporkan 790 kasus konfirmasi COVID-19 dari 24 Provinsi (Kementrian Kesehatan RI, 2020; Handayani, 2019; Sairah et al, 2019; WHO, 2020)

Coronavirus adalah keluarga besar virus yang menyebabkan penyakit mulai dari gejala ringan-berat. Terdapat dua jenis coronavirus yang diketahui menyebabkan penyakit dengan gejala berat, yaitu Middle East Respiratory Syndrome (MERS) dan Severe Acute Respiratory Syndrome (SARS). Menurut WHO virus ini merupakan zoonosis pada awal transmisinya, dimana hewan yang merupakan sumber penularan masih terus diteliti. Kemudian transmisi terjadi melalui kontak antar manusia (human-to-human transmission) via oleh droplet infeksius atau cairan tubuh dari penderita yang infeksius. Gejala COVID-19 dapat dibagi menjadi simptomatik dan asimptomatik. Gejala simptomatik umumnya memiliki gejala berupa demam, fatigue, myalgia, anoreksia, nyeri kepala dan gejala respirasi seperti batuk, dyspnea, nyeri tenggorokan, dan kongesti nasal (WHO, 
2020; WHO, 2020; Menteri dalam Negeri, 2020; Sousa et al, 2020). Menurut US Centers for Disease Control and Prevention (CDC) ibu hamil memiliki risiko tertular COVID-19 yang sama dengan orang dewasa yang tidak hamil. Penelitian yang telah dilakukan pada ibu hamil dengan COVID-19 menunjukkan bahwa ibu hamil jarang memiliki gejala respirasi yang berat dengan gejala klinis yang tipikal, karena secara fisiologis ibu hamil mengalami imunosupresi. Namun ada beberapa temuan yang menyatakan bahwa ibu hamil dapat mengalami gejala atipikal (Ryan et al, 2020; Liu H et al, 2020). Oleh karena itu penulis ingin mengetahui bagaimana karakteristik klinis yang dimiliki oleh ibu hamil dengan COVID-19.

\section{Metode}

Metode menggunakan studi pustaka dengan mengambil data dan referensi dari berbagai buku dan artikel ilmiah yang valid dengan publikasi 1 tahun terakhir. Artikel tersebut dicari melalui data dari NCBI, PubMed, Elsevier, The Lancet, dan Karger yang dibatasi dari 3 Agustus 2020 sampai dengan 10 Oktober 2020 menggunakan kata kunci berupa: pregnancy, COVID-19, clinical features, dan coronavirus. Selanjutnya literature melewati proses review yang sesuai dengan kriteria. Pencarian dengan menggunakan keyword diatas mendapatkan 42 literatur yang revelan. Sejumlah 18 artikel tidak memiliki kriteria inklusi, hanya 24 artikel yang kemudian disusun dalam literature review ini.

\section{Hasil Dan Pembahasan}

COVID-19 disebabkan oleh novel coronavirus yang diketahui sebagai Severe Acute Respiratory Syndrome Coronavirus-2 (SARS-CoV-2). Virus ini merupakan RNA virus berantai tunggal, dan merupakan bagian subgenus Sarbecovirus dalam subfamili Orthocoronaviridae. Virus ini merupakan virus ketujuh dalam angota family Coronaviridae yang menginfeksi manusia. Mayoritas pasien COVID-19 pada awalnya menunjukkan keterkaitan penularan dari pasar basah hewan laut di Wuhan, Cina. Keterkaitan ini apabila dilihat dari awal transmisinya, menunjukkan besar kemungkinan virus ini adalah zoonosis. Namun, hewan yang menjadi sumber penularan virus dan bagaimana transmisi dari hewan ke manusia masih belum diketahui, sampai saat ini peneliti masih terus meneliti hal tersebut. Beberapa studi filogenetik yang dilakukan menunjukkan nukleotida virus $79 \%$ homolog dengan coronavirus yang diisolasi dari kelelawar horseshoe (R.sinicus) dan 96\% dengan R.affinis (Handayani et al, 2019; Mackenzie J.S \& David W.S, 2020).

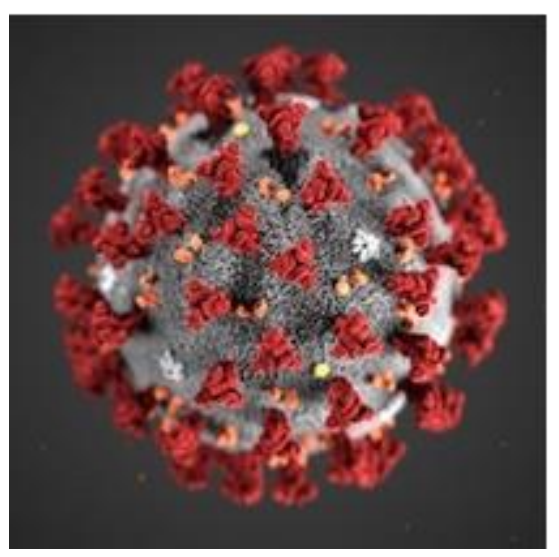

Transmisi virus menyebar sangat cepat melalui kontak antara manusia-ke-manusia (human-to-human contact) via droplet respiratorik dan saliva dari orang yang terinfeksi COVID-19. Transmisi melalui fomite juga dapat terjadi, dan baru-baru ini WHO mengkonfirmasi adanya transmisi melalui airbone. Berdasarkan genetic sequencing dan analisis filogenetik virus tersebut merupakan bagian dari genus betacoronavirus yang memiliki hubungan dekat dengan SARS. Penelitian lain menemukan kemiripan yang dimiliki COVID-19 dan SARS mencapai $76 \%$. Virus SARS-CoV-2 merupakan virus RNA berantai tunggal, dan memiliki masa. 
inkubasi 5-6 hari hingga 14 hari. Beberapa pasien kemungkinan ditemukan sangat contagious selama masa inkubasi ini, terutama 1-3 hari sebelum onset gejala klinis timbul (Mackenzie J.S \& David W.S, 2020).

Penderita COVID-19 yang sudah sembuh masih memiliki peluang yang sama untuk kembali tertular, belum ada penelitian yang membuktikan bahwa seseorang yang pernah terinfeksi dapat membentuk antibodi yang dapat melindungi penderita untuk kemungkinan tertular di kemudian hari. Menurut WHO penderita yang simptomatik umumnya memiliki peluang lebih besar untuk menularkan virus ke orang lain, dibandingkan dengan penderita yang asimptomatik. Hal ini diperkuat dengan tingginya viral load yang dideteksi pada throat swab dan nasal swab saat awal gejala klinis timbul. Semakin tinggi viral load yang ditemukan, terutama yang melebihi baseline akan menyebabkan gejala klinis yang timbul juga semakin berat. Viral shedding di faring sangat tinggi pada minggu pertama gejala klinis muncul dan sampai pada puncaknya pada hari keempat. Durasi median dari viral shedding ini berkisar 8-20 hari setelah gejala klinis hilang. Namun durasi viral shedding yang dideteksi pada feses umumnya lebih lama, yakini berkisar selama 22 hari. Terdapat beberapa faktor yang mempengaruhi panjangnya durasi viral shedding diantaranya adalah, jenis kelamin pria, usia lanjut, komorbid hipertensi, penggunakan ventilasi mekanik atau kortikosteroid yang invasive, dan terlambatnya diagnosis pasien dengan COVID-19 (late admission). Penelitian lain juga telah membuktikan tidak ada korelasi antara viral shedding dengan infektivitas seseorang (Mackenzie J.S \& David W.S, 2020).

Reproductive number (Ro) yang diperkirakan dari COVID-19 adalah sekitar 2.2-3.3, dan beberapa penelitian menyatakan bahwa Ro dapat menurun apabila diberlakukan social distancing. Virus ini ditemukan lebih stabil pada plastic dan baja (72 jam) dibandingkan dengan tembaga (4 jam) dan kayu (24jam). Beberapa studi lain menyatakan bahwa virus ini dapat dideteksi dalam darah, cairans serebrospinal, cairan perikardial, sekresi konjungtiva, jaringan plasenta, urin, semen, dan feses. Penelitian terbaru juga menemukan bahwa pada beberapa pasien dideteksi virus SARS-CoV-2 pada mastoid dan telinga bagian tengah. Patofisologi COVID-19 masih belum diketahui secara pasti, namun beberapa peneliti telah mengkonfirmasi adanya bukti bahwa virus berikatan dengan reseptor Angiotensin Converting Enzyme-2 (ACE-2). Setelahnya, virus akan menyebabkan downregulation ACE-2 yang mengakibatkan overakumulasi toksik dari plasma angiotensin-II yang akan menginduksi sindrom distres pernapasan akut dan miokarditis fulminan. Melalui analisis single-cell RNA sequencing datasets ditemukan bahwa organ yang cukup rentan pada infeksi virus akibat jumlah ekspresi ACE- fol yang berlebih adalah paru-paru, jantung, esophagus, ginjal, vesika urinaria, dan ileum. Temuan ini menjelaskan gejala ekstrapulmoner yang berasosiasi dengan infeksi (Mackenzie J.S \& David W.S, 2020; Frazier K.M et al, 2020).

Selain itu, COVID-19 juga berhubungan dengan kerusakan endotel, Endoteliopati dan aktivasi platelet merupakan temuan yang signifikan pada pasien-pasien yang jatuh dalam kondisi kritis. Hubungan yang potensial antara hiperviskositas dan komplikasi trombotik sampai saat ini masih diteliti. Derajat atau tingkat keparahan gejala klinis berdasarkan WHO dibagi menjadi empat nyaitu gejala klinis ringan, sedang, berat, dan kondisi kritis. Gejala klinis ringan ditandai dengan pasien tanpa hipoksia ataupun pneumonia, gejaa yang sering ditemukan adalah demam, batuk, dispnea, dan myalgia. Gejala klinis ringan tidak spesifik berupa sakit tenggorokan, kongesti nasal, nyeri kepala, diare, mual/muntah, dan kehilangan penciuman. Penderita usia lanjut dan imunospupresi pada umumnya menampilkan gejala klinis berupa fatigue, penurunan mobilitas, diare, hilangnya selera makan, delirium, dan tanpa demam. Gejala klinis ringan yang umumnya ditemui selama 
kehamilan adalah demam, dispnea, dan gangguan gastrointestinal. Gejala klinis sedang pada orang dewasa umumnya demam, batuk, dispnea, peningkatan kecepatan bernapas dan tidak ditemukan tanda pneumonia berat. Sedangkan pada anak-anak gejala klinis sedang biasanya berupa batuk, kesulitan bernafas, dan atau retraksi dinding dada tanpa gejala pneumonia berat. Gejala klinis berat ditandai dengan pneumonia dan salah satu dari kriteria: respiratory rate $>30 \mathrm{x} /$ menit, distress pernapasan berat, dan $\mathrm{SpO} 2<90 \%$ pada suhu ruangan. Kemudian kondisi kritis ditandai dengan timbulnya sindrom distres pernapasan akut, sepsis, dan syok septik serta komplikasi lain seperti embolisme pulmo akut, sindom coroner akut, stroke akut, dan delirium. Menurut National Institutes of Health gejala klinis COVID-19 dibagi menjadi asimptomatik, gejala klinis ringan, sedang, berat, dan kondisi kritis. Asimptomatik mengindikasikan penderita yang tidak menunjukkan gejala klinis namun dari hasil pemerikasaanya terbukti terinfeksi virus SARS-CoV-2. Gejala klinis ringan berupa demam, nyeri tenggorokan, batuk, malaise, sakit kepala, dan nyeri otot, tanpa ada dispnea, nafas pendek, dan temuan abnormal pada pencitraan. Gejala klinis sedang berupa gejala klinis respirasi bawah dengan pemeriksaan klinis atau pencitraan dan SpO2 $>90 \%$ pada suhu ruangan. Gejala klinis berat berupa respiratory rate $>30 \mathrm{x} /$ menit, an $\mathrm{SpO} 2 \leq 93 \%$ pada suhu ruangan atau rasio tekanan parsial oksigen arteri $\mathrm{PaO} 2$ dengan fraksi oksigen inspirasi (FiO2) $(\mathrm{PaO} 2 / \mathrm{FiO} 2<300)$ atau infiltrate paru $>50 \%$ (Mackenzie J.S \& David W.S, 2020)

Ibu hamil dengan COVID-19 berdasarkan gambaran klinis dapat dibagi menjadi tiga klasifikasi. Klasifikasi tersebut berdasarkan tingkat keparahan infeksi pada jalur respiratorik dan dibagi menjadi klinis ringan, sedang, dan berat. Klasifikasi ini membantu tenaga medis merencanakan tindakan dan penanganan cepat dan tepat dengan melihat derajat beratnya COVID-19 pada ibu hamil melalui gambaran klinisnya. Selain derajat klinis, American Thoracic Society and Infectious Diseases Society of America juga menambahkan skor CURB (Confusion, Urea, Respiratory Rate, Blood pressure) dalam melihat beratnya gejala klinis pasien. Gejala klinis ringan digambarkan sebagai ibu hamil yang mengalami gejala klinis lokal pada sistem pernapasan bagian atas (batuk, nyeri tenggorokan, rinore, dan kehilangan penciuman). Gejala klinis sedang merupakan gejala pneumonia ringan yang dikonfirmasi dengan menggunakan pemeriksaan rontgen thoraks, tidak diiringi dengan gejala berat ( $\mathrm{SO}$ bantuan ventilasi, dan skor CURB $\leq 1$ ) (Lopez et al, 2020).

Gejala klinis berat memiliki gambaran klinis berupa pneumonia berat atau distress pernapasan dan syok septik. Pneumonia berat dikatakan apabila pneumonia yang ditemukan bersamaan dengan salah satu dari: kegagalan organ $\geq 1$, basal SO2 $<90 \%$, respiratory rate $\geq 30 \mathrm{kali} /$ menit, dan membutuhkan vasopressor. Selain itu dapat juga ditemukannya distress pernapasan yang ditandai dengan gambaran klinis berupa dispnea, retraksi dada, dan usaha bernapas) atau temuan radiologis dari infiltrate bilateral pada paru dan defisit oksigen (rasio SO2/FiO2 <315 jika data $\mathrm{PaO} 2$ tidak tersedia, atau rasio $\mathrm{PaO} 2 / \mathrm{FiO} 2 \leq 300$. Syok septik memperlihatkan temuan hipotensi arterial yang menetap walaupun telah diberikan resusitasi cairan dan memerlukan vasopressor untuk mempertahankan mean arterial pressure (MAP) $\geq 65 \mathrm{mmHg}$ dan laktat $\geq 2 \mathrm{mmol} / \mathrm{L}$ $(18 \mathrm{mg} / \mathrm{dL})$ dalam kondisi tidak hipovolemik. Ibu hamil yang menderita COVID-19 dengan gambaran klinis yang berat umumnya dikatakan jatuh dalam kondisi yang kritis (Lopez et al, 2020). Menurut Lopez, et al mayoritas dari ibu hamil dengan COVID-19 memiliki gejala klinis yang ringan. Temuan pneumonia dengan gambaran infiltrate pada kedua lapang paru pada umumnya ditemukan pada $50 \%$ ibu hamil dengan gambaran klinis ringansedang. Temuan klinis ibu hamil yang jarang pada gejala klinis ringan adalah diare. Penelitian ini juga menyatakan bahwa ibu hamil yang terinfeksi COVID-19 tidak memiliki suseptibilitas yang lebih tinggi untuk berkembang menjadi gejala klinis yang berat dan 
komplikasi yang serius. Namun, perlu diperhatikan bahwa ibu hamil akan mengalami perubahan adapatasi fisiologis pada sistem kardiovaskular, respirasi, dan koagulasi dalam sistem hematologi yang dapat menyebabkan peningkatan risiko morbiditas (Lopez et al, 2020).

Diagnosis klinis ibu hamil dengan COVID-19 dilakukan melalui anamnesis, pemeriksaam fisik, dan pemeriksaan penunjang. Anamnesis yang cermat dilakukan untuk menentukan keluhan utama ibu hamil dan membantu tenaga kesehatan dalam menentukan derajat klinis ibu hamil. Umumnya keluhan ibu hamil sama dengan keluhan yang dikeluhkan pasien yang tidak hamil. Namun perlu diperhatikan gejala demam, dispnea, gejala gastrointestinal, dan fatigue mungkin overlap dengan perubahan adaptasi fisiologis selama kehamilan. Pemeriksaan fisik meliputi keadaan umum tanda vital, pemeriksaan jantung-parum dan lainnya yang sesuai dengan indikasi. Selanjutnya pemeriksaan penunjang seperti darah rutin, pencitraan paru, dan real-time reverse-transcription polymerase chain reaction (RT-PCR) untuk SARS-CoV-2 dengan sampel yang diambil melalui swab tenggorokan. Pemeriksaan penunjang berupa serologis tidak dianjurkan oleh WHO kecuali untuk kepentingan penelitian (Mackenzie J.S \& David W.S, 2020)

Menurut review article yang dilakukan Ryan, et al. dinyatakan bahwa ibu hamil dengan COVID-19 pada umumnya akan mengalami gambaran gejala klinis yang ringan. Hasil penelitian tersebut menyatakan sekitar $85 \%$ ibu hamil yang memiliki gambaran klinis ringan, sedangkan sekitar $10 \%$ ibu hamil memiliki gambaran klinis yang lebih berat (severe), dan 5\% ibu hamil jatuh dalam kondisi yang kritis. Gejala klinis yang umum ditemukan berupa demam, batuk, dispnea, dan diare. Pilihan persalinan baik vaginam atau cesarean section juga tidak mengubah beratnya gejala klinis yang dialami ibu hamil. Ibu hamil dengan komorbid meningkatkan risiko untuk memiliki gejala klinis yang lebih berat sama halnya dengan populasi umum (tidak hamil) dengan komorbid. Pada beberapa kasus sulit untuk membedakan dispnea fisiologis pada ibu hamil akibat peningkatan demand oksigen maternal karena peningkatan metabolisme, anemia gestasional, dan konsumsi oksgen fetus yang umumnya normal selama kehamilan dengan gejala klinis pada COVID19, sehingga pemeriksaan yang cermat tetap diperlukan (Ryan et al, 2019)

Kemudian studi lain yang dilakukan oleh Wu et al. juga memperlihatkan hasil yang serupa nyaitu sekitar 86\% ibu hamil penderita COVID-19 memiliki gambaran klinis ringan, 9,3\% memiliki gejala berat, dan 4,7\% berkembang menjadi kondisi kritis. Gejala klinis ringan yang paling sering ditemui adalah batuk dan kongesti nasal. Usia kehamilan juga tidak menunjukkan adanya pengaruh terhadap derajat klinis pada ibu hamil. Melalui hasil penelitian tersebut dinyatakan gejala klinis ibu hamil dengan yang tidak hamil adalah sama. Penelitian tersebut juga membuktikan ibu hamil dengan COVID-19 yang asimptomatik umumnya memiliki waktu rawat inap di rumah sakit yang lebih singkat apabila dibandingkan dengan ibu hamil yang simptomatik (Wu X et al, 2020; Arentz et al, 2020).

Tabel 1. Gambaran klinis yang umum ditemukan pada ibu hamil (Ryan et al, 2019)

\begin{tabular}{lcccc}
\hline \multicolumn{1}{c}{ Gejala Klinis } & $\begin{array}{c}\text { Dashraath,et al. } \\
\text { (\%) }\end{array}$ & $\begin{array}{c}\text { Yu,et al. } \\
\text { (\%) }\end{array}$ & $\begin{array}{c}\text { Chen,et al. } \\
\text { (\%) }\end{array}$ & $\begin{array}{c}\text { Elshafeey,et al. } \\
\text { (\%) }\end{array}$ \\
\hline Demam & 84 & 86 & 75 & 67.3 \\
Batuk & 28 & 14 & 73 & 65.7 \\
Dispnea & 18 & 14 & 7 & 7.3 \\
\hline
\end{tabular}




\begin{tabular}{lcccc}
\hline Limfopenia & - & 14 & 7 & 7.3 \\
Leukositosis & 38 & - & 44 & 14 \\
$\begin{array}{l}\text { Gejala lain; } \\
\text { sputum, rash, } \\
\text { hilang selera } \\
\text { makan, sakit } \\
\text { kepala }\end{array}$ & 22 & - & 6 & $<5$ \\
\hline
\end{tabular}

Menurut tabel systematic review di atas, gambaran klinis ibu hamil dengan COVID-19 yang paling sering ditemukan adalah demam. Batuk merupakan gambaran klinis tersering selain yang demam pada ibu hamil dengan COVID-19.

Sebuah studi yang baru saja dilakukan di Amerika Serikat memperlihatkan bahwa penderita COVID-19 yang hamil memiliki peluang untuk berkembang menjadi miokarditis viral dan kardiomiopati. Sampai saat ini, baru terdapat satu penelitian yang dilakukan Juusela, Nazir, dan Gimovsky, dimana dari hasil penelitian tersebut ditemukan 2 kasus ibu hamil COVID-19 dengan gambaran kardiomiopati. Kardiomiopati merupakan temuan klinis yang lebih sering ditemukan pada pasien COVID-19 yang tidak hamil dan mengalami kondisi kritis. Kehamilan merupakan keadaan immunocompromised dimana demand kardiovaskular meningkat, dan terjadinya respiratorik alkalosis yang terkompensasi dengan metabolik asidosis yang membuat ibu hamil rentan terhadap penyakit respiratorik seperti COVID-19. Penelitian mengenai apakah kehamilan dapat mengekserbasi perkembangan kardiomiopati COVID-19 masih terus dalam penelitian. Penelitian ini juga menekankan pentingnya pemeriksaan ekokardiogram pada ibu hamil dengan COVID-19 yang menunjukkan gejala pneumonia, terutama yang memerlukan bantuan terapi oksigen dan pada ibu hamil yang jatuh dalam kondisi kritis. Masih diperlukan berbagai data dan penelitian lanjut untuk menentukan insiden kardiomiopati pada ibu hamil yang menderita COVID-19 (Ryan et al, 2019; Juusela et al, 2020).

Penelitian yang dilakukan di Wuhan, China juga memperlihatkan hasil yang serupa pada gambaran klinis ibu hamil yang menderita COVID-19. Sekitar 109 (92\%) dari total $118 \mathrm{ibu}$ hamil yang positif COVID-19 mengalami gejala klinis yang ringan, sedangkan 9 ibu hamil (8\%) yang mengalami gejala klinis berat, dan 1 ibu hamil yang mengalami kondisi kritis. Hingga bulan Maret tahun 2020, 109 ibu hamil dari total 116 dinyatakan sembuh dan dapat kembali ke rumahnya. Tidak ditemukan kematian termasuk ibu hamil yang jatuh dalam kondisi kritis dan di rawat dalam instalansi rawat intensif (Chen et al, 2020)

Penelitian lain yang dilakukan di Cina dengan menganalisis gejala klinis pada sepuluh ibu hamil yang terkonfirmasi COVID-19, menyatakan bahwa tidak ada ibu hamil yang memiliki gejala klinis berat dan meninggal. Lima ibu hamil tersebut mengalami gejala klinis sesak dimana setelah dilakukan pencitraan dengan CT-Scan didapatkan gambaran efusi pleura. Peneliti menyatakan bahwa perkembangan efusi pleura kemungkinan disebabkan karena perubahan adaptasi fisiologis yang terjadi pada ibu hamil, sehingga gejala klinis yang non spesifik ini perlu dipertimbangkan saat menghadapi pasien hamil dengan COVID-19 (Cao et al, 2020). Penelitian retrospektif yang dilakukan di Wuhan, Cina menyatakan bahwa ibu hamil dengan kehamilan pada trisemester akhir memiliki prognosis yang lebih baik. Ibu hamil pada trisemester akhir tidak memiliki gejala klinis yang lebih berat walaupun pada penelitian tersebut tetap ditekankan bahwa usia kehamilan lanjut rentan dengan gejala klinis yang berat. Hal ini disebabkan karena perubahan kadar hormon yang tidak seimbang dan penurunan volume paru yang disebabkan oleh peningkatan ukuran uterus selama kehamilan (Yu et al, 2020). Analisis subgroup antara ibu hamil dengan COVID-19 dan penderita COVID-19 yang tidak hamil menunjukkan insiden demam dan batuk pada 
ibu hamil lebih rendah, hal ini kemungkinan dipengaruhi oleh perubahan sistem imun pada ibu hamil dan masih diperlukan penelitian lebih lanjut mengenai hal tersebut. Metaanalisis ini juga menunjukkan mortalitas ibu hamil dengan COVID-19 cukup rendah, namun hal ini tetap tidak menginterpretasikan bahwa kehamilan merupakan faktor proktektif terhadap gejala klinis yang lebih berat. Penelitian yang telah dilakukan sebelumnya menunjukkan bahwa gejala klinis berat terjadi pada penderita usia lanjut (>60 tahun), penderita dengan komorbid seperti diabetes, penyakit jantung koroner, hipertensi, penyakit serebrovaskular, dan penyakit kronik lainnya. Mayoritas ibu hamil rata-rata berusia muda dan jarang disertai dengan komorbid. Selain itu, ibu hamil dan keluarganya cenderung lebih teliti dalam menilai kesehatan dan perubahan yang terjadi pada kesehatan ibu tersebut. Sehingga apabila ada gangguan kesehatan pada ibu hamil, ia akan langsung dibawa ke fasilitas kesehatan untuk segera diperiksa sehingga dan hal ini berimplikasi pada penurunan keterlambatan dalam tatalaksana. Penanganan awal ini juga menurunkan risiko gejala klinis ibu hamil untuk berkembang menjadi berat (Gao et al, 2020; Zeng et al, 2020; Qiancheng et al, 2020)

Selanjutnya penelitian yang dilakukan oleh Zeng et al. mengungkapkan suatu fakta, nyaitu apabila dilakukan perbandingan antibodi IgG SARS-CoV-2 antara pria dan wanita, maka wanita dengan infeksi COVID-19 akan memiliki antibodi yang jauh lebih tinggi. Produksi antibodi ini sangat tinggi pada awal infeksi, dan ini yang menjelaskan mengapa wanita termasuk ibu hamil memiliki gejala klinis yang relatif lebih ringan dibandingkan dengan pria. Studi yang baru dipublikasikan oleh Zhou et al. menyatakan bahwa 2-3 minggu merupakan keytime yang menentukan kesembuhan pasien. Oleh karena antibodi IgG yang diproduksi sangat tinggi pada wanita, menyebabkan gejala klinis yang dialami lebih ringan dibandingkan dengan pria. Wanita memiliki dinamik antibodi IgG yang berbeda dengan pria, sehingga ini menjadi alasan mayoritas wanita termasuk ibu hamil dengan COVID-19 memiliki gejala klinis yang lebih ringan. Hasil penelitian ini diperkuat dengan penelitian yang dilakukan oleh Desmond, et al. di New York Presbyterian Allen Hospital dan Columbia University Irving Medical Center menunjukkan $87.9 \%$ ibu hamil yang melahirkan memiliki gejala klinis ringan-asimptomatik (Zheng et al, 2020).

\section{Simpulan Dan Saran}

Ibu hamil yang menderita COVID-19 secara umum tidak memiliki perbedaan gejala klinis dengan kelompok populasi umum yang tidak hamil. Mayoritas ibu hamil dengan COVID-19 memiliki gejala klinis ringan seperti demam, batuk, dan dispnea. Walaupun dalam beberapa penelitian dikatakan ibu hamil secara fisiologis mengalami imunosupresi, diperkirakan adanya peran antibodi IgG yang diproduksi lebih tinggi pada ibu hamil. Antibodi IgG ini berperan sebagai faktor protektif ibu hamil terhadap COVID-19, sehingga jarang gejala klinis yang timbul akan bermanifestasi dalam bentuk yang berat. Angka kematian, durasi rawat inap di rumah sakit dan keparahan klinis pada ibu hamil yang menderita COVID-19 umumnya rendah. Usia kehamilan juga tidak menentukan keparahan derajat klinis pada ibu hamil. Faktanya, kehamilan dengan komorbid meningkatkan risiko gejala klinis berat pada ibu hamil, sehingga besar kemungkinan ibu hamil dapat jatuh dalam kondisi kritis hingga kematian.

\section{Daftar Rujukan}

Arentz M, Yim E, Klaff L, et al. 2020. Characteristics and outcomes of 21 critically ill patients with COVID-19 in washington state. JAMA. 323(16):1612-1614.

British Medical Journal. 2020. Coronavirus disease 2019 (COVID-19). United Kingdom: 
BMJ

Cao, et al. 2020. Clinical analysis of ten pregnant women with COVID-19 in Wuhan, China: A retrospective study. / International Journal of Infectious Diseases. 95:294-300

Chen, et al. 2020. Clinical Characteristics of pregnant women with Covid-19 in Wuhan, China. NEJM. 382

Frazier K.M., et al. 2020. SARS-CoV-2 virus isolated from the mastoid and middle ear: implications for COVID-19 precautions during ear surgery. JAMA Otolaryngol Head Neck Surg. 1-2.

Gao, et al. 2020. Clinical features and outcomes of pregnant women with COVID-19: a systematic review and meta-analysis. BMC Infectious Diseases. 20:564

Handayani, et al. 2020. Penyakit virus corona 2019. J Respir Indo. 40(2):119-127.

Juusela A, Nazir M, Gimovsky M. 2020. Two cases of coronavirus 2019-related cardiomyopathy in pregnancy. Am J Obstet Gynecol MFM.

Kementrian Kesehatan RI. 2020. Pedoman pencegahan dan pengendalian coronavirus disease (COVID-19). Jakarta: Kemenkes RI dan Direktorat Jenderal Pencegahan dan Pengendalian Penyakit (P2P)

Liu H, Liu F, Li J, Zhang T, Wang D, Lan W. 2020. Clinical and CT imaging features of the COVID-19 pneumonia: Focus onpregnant women and children. J Infect. 80(5):7-13.

Lopez, et al. 2020. Coronavirus Disease 2019 in Pregnancy: A clinical anagement protocol and considerations for practice. Fetal Diagn Ther. (47):519-528.

Mackenzie, J.S., David W.S. 2020. COVID-19: a novel zoonotic disease caused by a coronavirus from china: what we know and what we don't. MICROBIOLOGY AUSTRALIA

Mentri dalam Negri. 2020. "Pedoman Umum Kesiapsiagaan Menghadapi Penyakit Coronavirus (2019-nCoV) untuk Pemerintah Daerah. Jakarta

Qiancheng, et al. 2020. Coronavirus disease 2019 in pregnancy. International Journal of Infectious Diseases. 95:376-383.

Ryan et al. 2020. Clinical update on COVID-19 in pregnancy: A review article. J. Obstet. Gynaecol. (46)8:1235-1245

Sairah. B., Baloch, M. A., T. Z., \& X. P. 2020. The Coronavirus Disease 2019 (COVID-19) Pandemic. Tohoku J. Exp. Med. 250(4), 271-278.

Sousa, et al. 2020. Effects of COVID-19 infection during pregnancy and neonatal prognosis: what Is the evidence?. Int. J. Environ. Res. Public Health 17(11):4176

World Health Organization (WHO). 2020. Coronavirus disease 2019 (COVID-19) Situation Report-10. Geneva: WHO

World Health Organization (WHO). 2020. Clinical Management of COVID-19; Integrim Guidance. Geneva: WHO

World Health Organization (WHO). 2020. Global COVID-19 Clinical Platform with pregnancy module. Geneva: WHO

Wu X, Sun R, Chen J, Xie Y, Zhang S, Wang X. 2020. Radiological findings and clinical characteristics of pregnant women with COVID-19 pneumonia. Int J Gynaecol Obstet. (150):58-63

Yu, et al. 2020. Clinical features and obstetric and neonatal outcomes of pregnant patients with COVID-19 in Wuhan, China: a retrospective, single-centre, descriptive study. The Lancet Infectious Disease. 20(5):559-564

Zeng, et al. 2020. A comparison study of SARS-CoV-2 IgG antibody between male and female COVID-19 patients: A possible reason underlying different outcome between sex. J Med Virol. 1-5. 